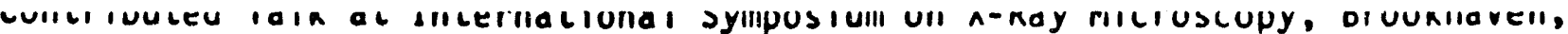
Aug. 31 - Sept. 4, 1987. Proceedings to be published by Springer Verlag.

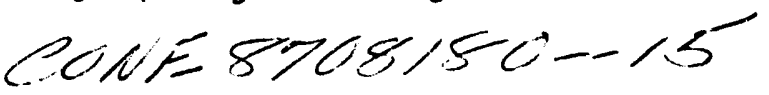

\title{
Soft X-Ray Laser Microscopy
}

D. DiCiccola), L, Meixler, C.H, Skinner, S. Suckewer,

J. Hirschherq, $(b)$ and E. Kohen $(b)^{k}$

Princeton University Plasma Physics Laboratory

Princeton, New Jersey 08544 USA

CONF-8708180--15

DE93 007317

\section{Introduction}

Microscopes based on soft $x$-ray lasers possess unique advantages in bridging the gap between high resolution eiactron microscopy of dehydrated, stained cells and light microscopy at comparatively low resolution of unaltered live cells. The high brightness and short pulse duration of soft $X$-ray lasers make them ideal for flash imaging of live specimens.

The Princeton soft $X$-ray laser is based on a magnetically confined laser produced carbon plasma. Radiation cooling after the laser pulse produces rapid recombination which produces a population inversion and high gain. A full account is given in a companion paper in this volume [1]. The important characteristics of the laser beam produced hy this device are 1 to $3 \mathrm{~mJ}$ of $18.2 \mathrm{~nm}$ radiation in a 10 to $30 \mathrm{nsec}$ pulse with a divergence of $5 \mathrm{mrad}$. The $18.2 \mathrm{~nm}$ wavelength, while outside

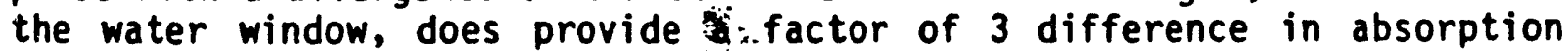
coefficients between oxygen and carbon.

\section{Status of Microscopy at Princeton}

Figure 1 shows a schematic of the Princeton soft $X$-ray laser experiment. Mult channel XUV spectrometers are normally used to monitor $X-$ ray emission from the plasma. During microscopy experiments the soft $x$-ray beam is diverted 20 deg. via an astigmatic spectacle lens which serves as a rudimentary toroidal grazing incidence mirror. Figures $2 \mathrm{a}$ and $2 \mathrm{~h}$ give views of the mirror, the positioning system, and the rear portion of the environmental cell. The translators are remotely controlled and allow us to steer the $x$-ray beam to the environmental cell. The alignment is optimized by temporarily placing a PIN diode detector at the environmental cell position.

\section{DISCLAIMER}

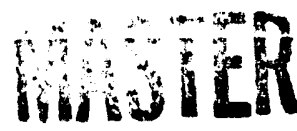

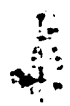

$F G 02.86 t R 13609$
This report was prepared as an account of work sponsored by an agency of the United States Government. Neither the United States Government nor any agency thereof, nor any of their employees, makes any warranty, express or implied, or assumes any legal liability or responsibility for the accuracy, completeness, or usefulness of any information, apparatus, product, or process disclosed, or represents that its use would not infringe privately owned rights. Reference herein to any specific commercial product, process, or service by trade name, trademark, manufacturer, or otherwise does not necessarily constitute or imply its endorsement, recommendation, or favoring by the United States Government or any agency thereof. The views and opinions of authors expressed herein do not necessarily state or reflect those of the 8

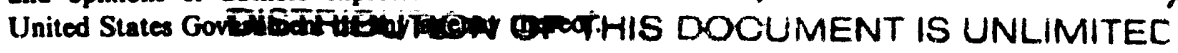




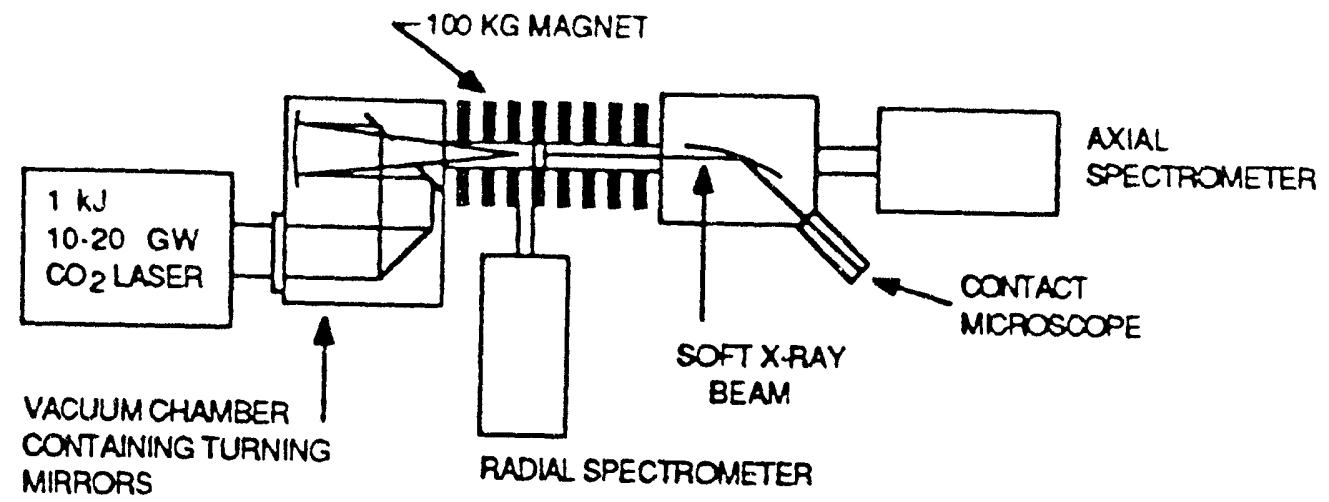

Fig. 1 Schematic of the Princeton Soft $X$-Ray Laser Experiment

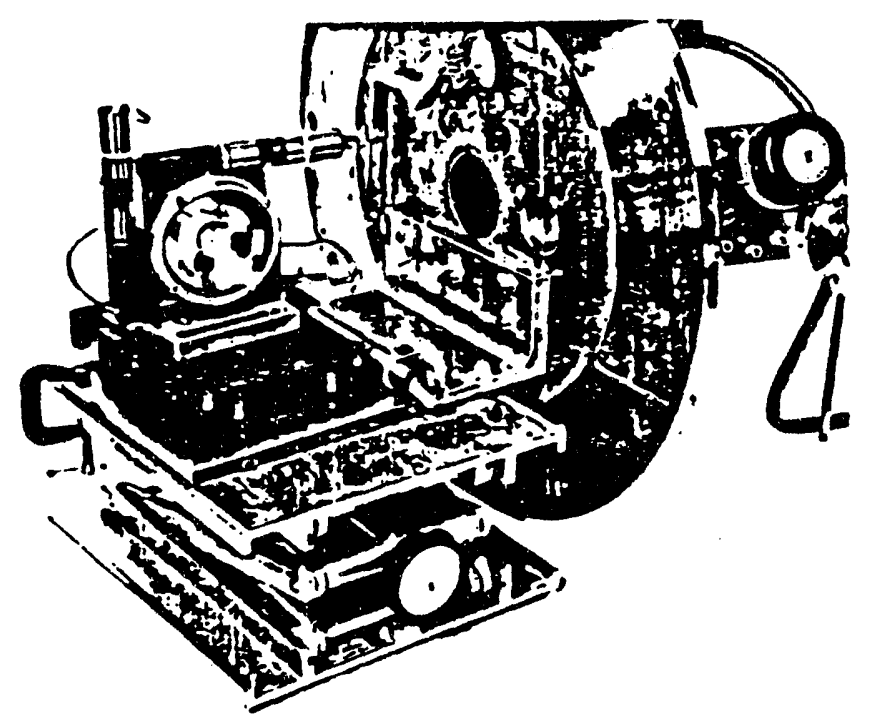

Fig. 2a View of the grazing incidence mirror

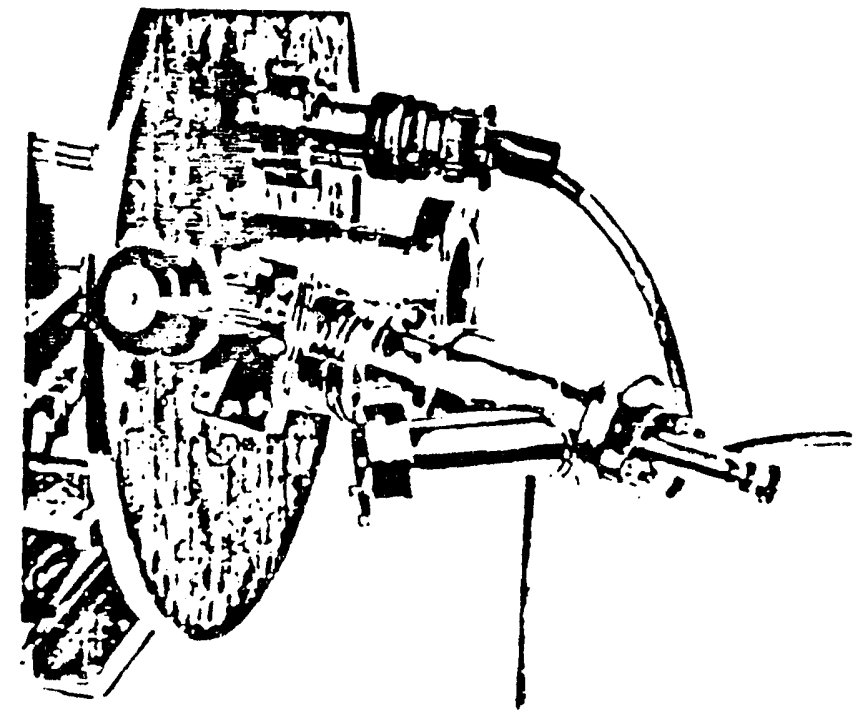

Fia. 2t View of the microscons 
Our environmental cell design follows the arrangement used by Feder et a1. [2]. A silicon nitride window serves as the vacuum interface. The window is $200 \mu \mathrm{m} \times 200 \mu \mathrm{m} \times 120 \mathrm{~nm}$ chick and is coated with 100 $\mathrm{nm}$ of aluminum. The $A$ I acts as a UV rejection filter and also lends some mechanical support to the membrane. Initial experiments have been performed in order to evaluate the performance of the system without the complications involved in handling live specimens. The first of this series used a piece of $\$ 100$ wire mesh in place of a living cell. Images of this mesh were recorded on Kodak $101 \mathrm{fi}$ im and on P(MMA co $M A A)$ resist and may be seen in figs. $3 a$ and $3 b$.

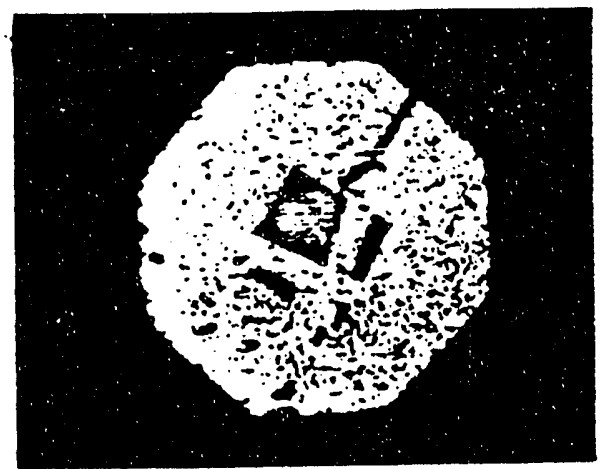

Fig. 3a Image of mesh on Kodak 101 with $\mathrm{Si}_{3} \mathrm{~N}_{4}$ window and Al filter (one laser shot)

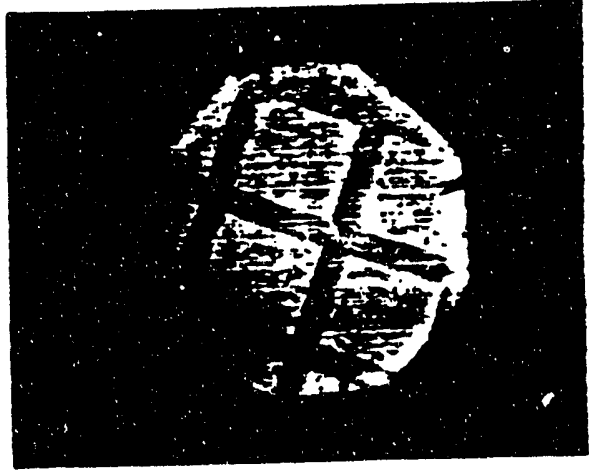

Fig. 3b Image of mesh on P(MMA co MAA) (one laser shot)

E: $:$ of the above images were generated with one laser shot. They $c==$ orly in fact that the resist image was obtained without the is $c^{*}$ the aluminur. coated silicon nitride wincsir so a contribution fro- Uli light from the plasma cannot be ruled ous at this time. The $P$ (Mli co Mifi) resist was developed in equal parts of methyl iso-buty? ketone and isopropenol. Images obtained or resist with the wincon in place were too faint to be clearly identifiatle usiria a meta?luraical microscode and an effort is being made to observe these imiags ir ar. SEli. In the near future the rudimentary grazinc inciderice mirror vill be replaced by a diamond turned ellipsoidel rarar af much suderiar optical quality. We anticipate a two orders c: magnitude increase in soft $x$-ray intensity at the environmental chamber which should eriable the resisi to be $w E 11$ exposed. 


\section{Microscope Development}

In future work we plan to use the contact microscope to examine live specimens. The cells will be placed or grown on a suitable resist-coated substrate. This would be brought into contact with the window and exposed with the laser beam. Subsequently, the resist would be ultrasonically cleaned, developed, and examined either by phase or electron microscopy.

In addition a new type of soft $x$-ray laser microscope, which has already been constructed, will be installed on the soft $X$-ray laser in the near future. Called COXRALM (Composite Optical X-Ray Laser Microscope), this device is an inverted phase contrast microscope with the capability of observing UV induced fluorescence combined with the option of contact micrograph generation via flash soft $X$-ray exposure. COXRALM, which is a collaborative effort by Biologists and Physicists, will provide the advantage of being able to observe the specimen up until the time of $x$-ray exposure. This will directly address the question of specimen condition at exposure and aid in the interpretation of contact micrographs.

\section{Acknowledgements}

We would like to thank P.C. Cheng for helpful advice regarding technique and sample preparation and $T$. Bennett for help with photography. We would also like to thank IBM Watson Research Center for providing the silicon nitride windows and the copolymer resist. This work was made possible by financial support from the U.S. Department of Energy, Basic Energy Sciences, the U.S. Air Force Office of Scientific Research and NRL/SDIO.

(a) PXL Inc., 1-H Princeton Corporate Plaza, Deerpark Drive, Monmouth Jct., New Jersey 08852

(b) Physics Department, University of Miami, Coral Gables, Florida 33124

\section{References}

1. C.H. Skinner, D.E. Kim, A. Wouters, D. Voorhees, and S. Suckewer: X-Ray Laser Sources for Microscopy, this volume.

2. R. Feder, J.W. McGowan, and D. Shinozaki: Examining the Submicron World, Plenum Publishing Company, (1986).

3. S. Suckewer, C.H. Skinner, H. Milchberg, C. Keane, and D. Voorhees: Phys. Rev. Lett. 55, 1753 (1985).

4. G. Schmahl and D. Rudolph: X-Ray Microscopy, Proceedings of the International Symposium, Gottingen, Federal Republic of Germany, Sept. 14-16, 1983, Springer Series in Optical Science 43, Springer Verlag 1984.

5. E. Spiller: High Resolution Soft $X$-Ray Optics, Proceedings of the SPIE, Brookhaven, New York, Nov. 18-20, 1981, SPIE 316, 1981. 

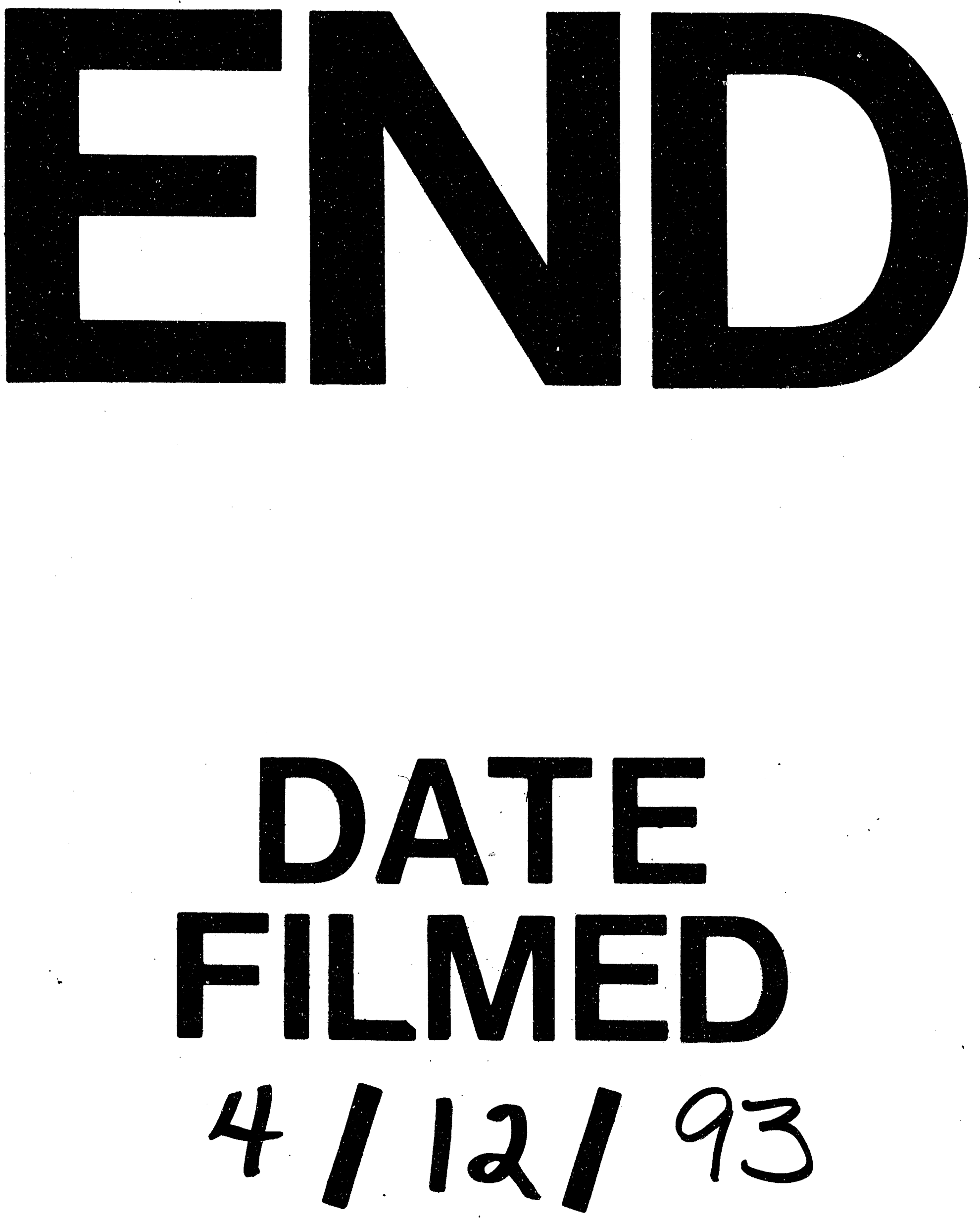


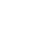

